Article

\title{
The Relationship between Image, Legitimacy, and Reputation as a Sustainable Strategy: Students' Versus Professors' Perceptions in the Higher Education Sector
}

\author{
Cristina Del-Castillo-Feito * ${ }^{\mathbb{B}}$, Alicia Blanco-González and Rafael Delgado-Alemany \\ Business Economics Department, Social Science Faculty, Rey Juan Carlos University, Madrid 28032, Spain; \\ alicia.blanco@urjc.es (A.B.-G.); rafael.delgado@urjc.es (R.D.-A.) \\ * Correspondence: cristina.delcastillo@urjc.es
}

Received: 30 December 2019; Accepted: 3 February 2020; Published: 6 February 2020

check for updates

\begin{abstract}
Higher education institutions operate in a highly competitive sector where attracting resources has become a complicated task. Intangible assets such as image, legitimacy, and reputation have been considered as crucial elements for the survival and success of organizations. Within the literature, authors have highlighted their relevance; however, the differences and relationships between these variables remains unclear. Under these circumstances, the aim of this paper is to measure the relationship between image, legitimacy, and reputation in the Public University as part of a sustainable strategy. This evaluation will be made considering students' and professors' perceptions to compare the results because many authors have highlighted the complexity of managing the relationship with these groups and obtaining positive assessments due to their diverse characteristics. To meet this objective, a review on the literature will be carried out, followed by analysis of the results obtained through a survey distribution. To treat the data, PLS-SEM (Partial Least Square) was used, and the corresponding measurement invariance of composite method (MICOM) and multigroup analysis (MGA) was carried out. The results confirm the proposed hypotheses on the relationship between the three variables; however, the moderating effect of the stakeholder group was not confirmed. The findings provide additional empirical evidence on the relationship between the considered variables as well as on considering more than one stakeholder group for the analysis. Managers could apply this information to improve their university's image, reputation, and legitimacy.
\end{abstract}

Keywords: higher education; image; reputation; legitimacy; sustainable strategy

\section{Introduction}

Higher education institutions operate in a highly competitive market [1] where attracting resources has become a complicated task. Globalization has expanded the competition to international levels because universities need to compete globally to attract talented students, prestigious professors, and employees [2-6]. Furthermore, despite the existing criticism [7], stakeholders' expectations regarding the scores held by universities in rankings are increasing, augmenting the pressure in the sector.

Apart from the increased competition, universities are no longer untouchable entities that can assume that society would trust them without being questioned [6]. Stakeholders are skeptical because universities have been focusing their efforts on research instead of teaching, handling money in non-transparent manners or lowering their efforts to serve the public in the correct way [8]. 
Many scholars consider that intangible assets and their correct implementation create benefits and competitive advantages for organizations $[9,10]$. Therefore, introducing image, legitimacy, and reputation as part of the elements to be managed [5] could be crucial for universities in their aim to achieve a sustainable development in the market.

Image, legitimacy, and reputation are considered critical variables for organizations' survival and success $[11,12]$. In the higher education context, holding a positive image, legitimacy, and reputation can improve an institution's competitive position [13], it can help an organization regain public trust through the correct management and communication with its stakeholders, or can reduce uncertainty [14] for stakeholders in their decision-making processes [15]. Due to their relevance, numerous scholars have developed research on these constructs; however, there are still doubts between the differences and relationships between them, and further research on this matter remains important.

Legitimacy can be granted by multiple sources, each one of them using a different routine for the evaluation [16]. A similar situation is faced when managing reputation because different dimensions of corporate reputation can be identified based on the diverse types of stakeholders perceiving the reputation of the firm $[17,18]$. In addition, higher education image formation will vary between different stakeholder groups [19] because they are affected by different stimuli. Therefore, it is important to understand the relevance of analyzing different audiences' perceptions [20].

Under these circumstances, the aim of this research is:

- First, to analyze the relationship between image, legitimacy, and reputation because, as it has been stated before, additional empirical evidence is needed because few papers cover this gap.

- Second, to apply this research to the higher education sector because the competition has increased and, due to the intangible nature of the service sector, its quality might be difficult to evaluate before it is experienced. Therefore, the importance of intangible assets for their success in attracting resources could be even more important.

- Third, to compare the perceptions that students and professors have because most of the research on the higher education field has considered only one stakeholder group and many authors highlight the complexity of managing intangible assets in universities given their different stakeholders.

To meet this objective, a review on the literature on image, legitimacy, and reputation, as well as on their relationships, will be carried out, followed by an empirical analysis. Finally, the main conclusions, limitations, and future research lines will be presented.

\subsection{Image, Legitimacy, and Reputation in the Higher Education Sector}

Given the increased amount of organizations offering similar products and services and competing to attract resources, the ability to differentiate through tangible aspects has become a greater challenge, therefore, the importance of introducing intangible asset management as part of the businesses core activities has become a determinant point in achieving a competitive position in almost any sector.

Previous research has demonstrated the existing relationship between value creation and competitive advantage and these intangible assets because their correct implementation created benefits for organizations $[9,10]$. Therefore, intangible assets could be considered as part of an organization's sustainable strategy to achieve long-term survival and success.

Within the higher education sector, increases in demand have motivated the expansion of the supply in terms of number and variety of offers [21]. Globalization has expanded the competition to international levels because universities must compete at international levels to attract resources, students, and professors [2]. In addition, a decrease in government funding has contributed to the development of private institutions in the sector [1]. The existing competitive scenario has also augmented the pressure for higher education institutions regarding their positions in rankings because stakeholders consider these positions as relevant factors when they decide which university to engage with [7]. 
Higher education institutions have understood the importance of managing intangible assets such as image, legitimacy, and reputation to differentiate themselves over competitors and to improve the relationship with their stakeholders [22].

\subsection{Image}

Universities are assigning more resources to manage their image and improve it in their stakeholders' eyes [23]. Holding a positive image could increase higher education institutions' competitive positions [13].

Despite the relevance that holding a positive image has for universities, there is still lack of empirical research to understand its management completely $[20,24,25]$. However, some authors have tried to overcome this situation. Lafuente-Ruiz-de-Sabando, Zorrilla, and Forcada [1] highlighted the lack of agreement on the dimensions forming the construct, the lack of clarity on the similarities and differences between image and reputation for stakeholders, and the limited measurement tools to include different stakeholders' perceptions because most of the research focused only on one stakeholder group.

A university's image has been defined as "the public's perception of the university" [26], or as "the sum of all beliefs an individual has towards the university" [24].

Higher education image formation will vary between different stakeholder groups [19] because they are affected by different stimuli and have different interests in the organization. Therefore, analyzing different audiences' perception and identifying the differences will be an interesting aspect to cover [20].

\subsection{Legitimacy}

Universities are facing pressure from stakeholders to adopt certain structures and to follow specific procedures in order to be considered legitimate [27]. Groups in the academic field have started to consider that these institutions need to renovate their legitimacy to gain the right to exist [28].

Moreover, some authors have considered that higher education institutions have been developing actions harming their legitimacy because they have been straying from their original missions of serving the public good [29].

Obtaining and maintaining legitimacy is a complex issue for higher education institutions due to the diverse characteristics of the different stakeholders whose demands they try to meet [30]. When trying to understand the needs and expectations of the given groups, universities understand that not every group has the same influence on assessing legitimacy [31]; therefore, the institution will not be equally responsive with every stakeholder group [32].

Despite the relevance of legitimacy for higher education institutions, few empirical papers exist within the literature. In fact, most of the research on measuring legitimacy in the higher education field appears to be related to specific practices more than to institutions $[32,33]$.

\subsection{Reputation}

In the higher education sector, due to its intangible nature [34], reputation will serve as a quality sign as well as an indicative of the institution's capacity to respond to stakeholders' needs in the correct manner [35]. It will reduce uncertainty [14] for stakeholders in their decision-making processes [15,36]. Therefore, obtaining a positive reputation will determine the university's survival given the competition in the sector $[22,37]$.

Despite the importance of achieving and maintaining a good reputation towards the different institution's stakeholders, there is still lack of clarity on its management, and it continues to be a challenge for universities [38-41]. Among the several reasons for this complexity, the following aspects could be highlighted: The heterogeneity in terms of stakeholders and, as a consequence, the differences in their expectations $[39,42]$ and the complexity related to the different types of educational institutions [34]. 
Šontaitė and Bakanauskas [38] defined reputation as a subjective and collective recognition of higher education institutions among all key stakeholders during a certain period, taking into consideration their past behavior, communication, and potential to satisfy expectations in comparison with the competition.

Most of the research within the higher education field has considered limited stakeholders for their empirical research [26,35,43]. Ali, Lynch, Melewar, and Jin [44] highlighted the fact that reputation value is moderated by the stakeholder group and country under consideration. Therefore, authors such as $[6,34,39]$ have tried to cover this gap with the introduction of the analysis of more than one stakeholder.

\subsection{Relationships between Image, Legitimacy, and Reputation}

There is not enough empirical research identifying if there is a clear relationship between all three variables. Within some of the common traits between image, legitimacy, and reputation, the benefits that they provide, as well as the consideration of stakeholders' perceptions for their formation, can be highlighted [45].

Most of the research agrees on them being different but related variables. When considering image and legitimacy, Tran, Nguyena and Melewar, etc., [46], as well as MacLean and Behnam, [47] analyzed the relationship between the compliance programs and the legitimacy perceptions and showed how compliance programs were able to project an acceptable and appropriate image and organizational legitimacy, demonstrating the effect that a positive image had on the institution's legitimacy. In addition, Metzler [48] analyzed the effect that repair image campaigns had on the organization's legitimacy. In this empirical research, the author supported that an improvement in an organization's image can have a positive impact on its legitimacy as well.

Hypothesis 1. Universities with higher image will have higher legitimacy.

In the case of image and reputation, the images held by different stakeholder groups will impact on the organization's reputation over a longer period [49]. Therefore, reputation will be the result of being able to maintain a strong image over time, so image will affect reputation [46]. Better corporate image results in a better reputation [50]. Therefore, reputation could be understood as the result and outcome of building and maintaining corporate image because an organization's reputation is shaped by the images of the given institution [51]. Podnar and Golob [52] supported the idea of the dependence that an entity's reputation has on the day-to-day images held by its stakeholders and argues the need for additional research on the relationships and differences between image and reputation in order to clarify this matter.

Hypothesis 2. Universities with higher image will have higher reputation.

When analyzing legitimacy and reputation, Deephouse and Suchman [16] considered that legitimacy affects reputation because legitimate organizations are positioned as trustworthy and reliable within their social environment; therefore, this can affect reputation in a positive way. King and Whetten [53] considered that legitimacy and reputation were used by an organization's stakeholders to evaluate the quality of that entity and if it is appropriate. Reputation can be considered as the result from the legitimation process [54] or the extension of legitimacy [53]. Organizations gain legitimacy and cultural support within their institutional environment to develop their reputation $[54,55]$.

Bansal and Roth [56] concluded that legitimacy issues could influence a firm's reputation and long-term survival and success. Doh, Howton, Howton, and Siegel [57] argued that legitimacy could be considered as a potential requirement for reputation, understanding legitimacy as an antecedent of reputation [53].

Authors have considered that the transmission of legitimacy values might enhance the company's competitive advantage and, therefore, its reputation [58]. Czinkota, Kaufmann, and Basile [59] viewed 
legitimacy as a requirement for the organization's social acceptance as well as for the development of reputation strategies.

Hypothesis 3. Universities with higher legitimacy will have higher reputation.

In addition, the current situation faced by organizations involves following the stakeholder theory where entities should be managing their relationships with their different stakeholders [60] in order to create value and mutual benefits with them. Under these circumstances, universities should be identifying their different stakeholder groups and adapting to their needs and demands when managing their legitimacy, image, and reputation. As it has been previously stated, many authors have highlighted the complexity of this matter due to the diverse characteristics that universities' stakeholder groups have in terms of age, knowledge, etc. In the literature, most of the research developed has focused only on one stakeholder group [35,43]; only a few of them have analyzed the legitimacy, image, or reputation in the higher education field by introducing more than one stakeholder [6,34]. Many scholars emphasize the importance of increasing the number of stakeholders $[17,42]$ under study to expand the knowledge on this issue. Considering this situation, the following hypothesis is proposed as an extension of the three previous hypotheses established:

Hypothesis 4. The relationship between image, legitimacy, and reputation is moderated by stakeholder groups.

The following figure (Figure 1) presents the proposed model and hypotheses.

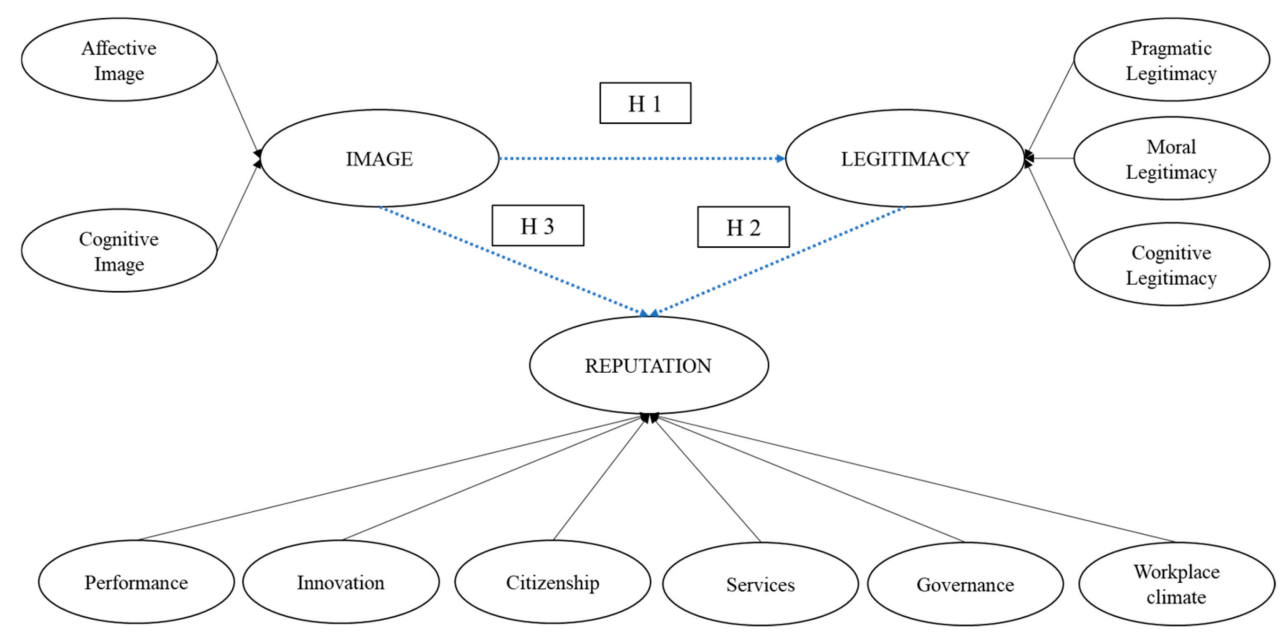

Figure 1. Proposed model and Hypotheses. Source: Own elaboration. (Note: H1 = Hypothesis $1 ; \mathrm{H} 2=$ Hypothesis 2; and H3 = Hypothesis 3).

\section{Materials and Methods}

Because competition has strengthened in the higher education sector, this analysis was applied to Spanish Public Universities. Information from a Spanish Public University's internal and external stakeholders (professors and students) was gathered (Table 1). The data was collected through the distribution of a questionnaire. First, a pre-test was distributed to 300 students to verify the scale and to adapt, if needed, the questions of the survey. After analyzing the results of the pre-test, some questions where modified to offer a clearer meaning and others were removed. In the final stage, a total of 756 effective responses were considered (618 students and 138 professors).

Regarding the measurement scale, the constructs were measured through adapted items from existing scales and used an 11-points Likert scale (0: strongly disagree; 10: strongly agree). The considered items used to measure the variables were: legitimacy [11,30,61-63], image [64], and reputation $[6,34,39]$. Table 2 shows the measurement instrument with the questions asked to measure the three variables. 
Table 1. Technical characteristics of the study.

\begin{tabular}{cc}
\hline Population Universe & Spanish Public University \\
\hline Sampling technique & Random \\
Method of collecting information & Online survey \\
Person surveyed & Students and professors from a Spanish Public University \\
Population & Students $=38,035 ;$ Professors $=1543$ \\
Sample size & Students $=618 ;$ Professors $=138$ \\
Dates of information collection & From 1 May 2018 to 1 July 2018 \\
\hline
\end{tabular}

Table 2. Measurement instrument.

\begin{tabular}{|c|c|c|}
\hline Factor & Item & Description \\
\hline \multicolumn{3}{|l|}{ LEGITIMACY } \\
\hline \multirow[t]{3}{*}{ Pragmatic Legitimacy } & LEGP1 & My university offers me a personal benefit \\
\hline & LEGP2 & It helps me to grow \\
\hline & LEGP3 & My university satisfies my needs \\
\hline \multirow[t]{3}{*}{ Moral Legitimacy } & LEGM1 & My university follows the law \\
\hline & LEGM2 & It behaves in an honest manner \\
\hline & LEGM3 & It is socially responsible \\
\hline \multirow[t]{3}{*}{ Cognitive Legitimacy } & LEGCOG1 & I know the activities that my university does \\
\hline & LEGCOG2 & I consider that these activities and actions are performed in the best possible manner \\
\hline & LEGCOG3 & My university is well managed \\
\hline \multicolumn{3}{|l|}{ REPUTATION } \\
\hline \multirow[t]{3}{*}{ Performance } & RPPERF1 & My university has a high research level \\
\hline & RPPERF2 & It obtains lucrative job placements \\
\hline & RPPERF3 & It has growth perspectives \\
\hline \multirow[t]{2}{*}{ Innovation } & RPIN1 & It adapts quickly to change \\
\hline & RPIN2 & It uses innovative teaching methods \\
\hline \multirow[t]{3}{*}{ Citizenship } & RPCSR1 & It exerts positive influence on society \\
\hline & RPCSR2 & It supports good causes \\
\hline & RPCSR3 & My university cares about their stakeholders' well being \\
\hline \multirow[t]{3}{*}{ Services } & RPSER1 & The formative offer responds to market trends \\
\hline & RPSER2 & It trains competent students \\
\hline & RPSER3 & It has good value for money \\
\hline \multirow[t]{3}{*}{ Governance } & RPGOV1 & There is a clear vision of the objectives that guide my university \\
\hline & RPGOV2 & It is managed with ethics and transparency \\
\hline & RPGOV3 & It takes into consideration its stakeholders in their management decisions \\
\hline \multirow[t]{3}{*}{ Workplace climate } & RPWORK1 & My university's professors are competent \\
\hline & RPWORK2 & The administrative personnel are competent \\
\hline & RPWORK3 & In general, my university is a good place to work \\
\hline \multicolumn{3}{|l|}{ IMAGE } \\
\hline \multirow[t]{4}{*}{ Cognitive Image } & IMAGCOG1 & My university has good facilities \\
\hline & IMAGCOG2 & It offers a good range of courses \\
\hline & IMAGCOG3 & It is orientated and concerned about its stakeholders' interests \\
\hline & IMAGCOG4 & It is a prestigious university \\
\hline \multirow[t]{3}{*}{ Affective Image } & IMAF1 & My university is pleasant \\
\hline & IMAF2 & It is stimulating \\
\hline & IMAF3 & Ii is dynamic \\
\hline
\end{tabular}

To treat the data, SmartPLS (Partial Least Squares) was used to estimate the model and to develop the multigroup analysis (MGA). This technique was chosen due to the benefits that it provides for this type of analysis as well as for the possibilities of developing the multigroup comparison [65-67]. 


\section{Results}

In the following table (Table 3), the values of the considered constructs are presented through the descriptive analysis. The average value for the three variables differs when considering the evaluations made by students and professors.

Table 3. Descriptive analysis.

\begin{tabular}{|c|c|c|c|c|c|c|c|}
\hline \multirow[b]{2}{*}{ Factor } & \multirow[b]{2}{*}{ Item } & \multicolumn{3}{|c|}{ Students } & \multicolumn{3}{|c|}{ Professors } \\
\hline & & Mean & SD & Average & Mean & SD & Average \\
\hline \multirow{3}{*}{ Performance } & RPPERF1 & 6.084 & 2.044 & \multirow{3}{*}{6.160} & 6.934 & 2.044 & \multirow{3}{*}{7.605} \\
\hline & RPPERF2 & 5.939 & 1.724 & & 7.948 & 1.724 & \\
\hline & RPPERF3 & 6.456 & 1.765 & & 7.932 & 1.765 & \\
\hline \multirow{2}{*}{ Innovation } & RPIN1 & 6.167 & 2.098 & \multirow{2}{*}{5.660} & 7.835 & 2.098 & \multirow{2}{*}{7.654} \\
\hline & RPIN2 & 5.152 & 1.993 & & 7.472 & 1.993 & \\
\hline \multirow{3}{*}{ Citizenship } & & 5.994 & 2.163 & \multirow{3}{*}{5.881} & 8.096 & 2.163 & \multirow{3}{*}{7.453} \\
\hline & RPCSR1 & 6.294 & 2.129 & & 7.341 & 2.129 & \\
\hline & & 5.355 & 2.286 & & 6.923 & 2.286 & \\
\hline \multirow{3}{*}{ Services } & RPSER1 & 6.723 & 1.687 & \multirow{3}{*}{6.010} & 8.221 & 1.687 & \multirow{3}{*}{8.000} \\
\hline & RPSER2 & 6.314 & 2.118 & & 7.852 & 2.118 & \\
\hline & RPSER3 & 4.992 & 2.033 & & 7.927 & 2.033 & \\
\hline \multirow{3}{*}{ Governance } & RPGOV1 & 5.480 & 2.641 & \multirow{3}{*}{5.860} & 5.645 & 2.666 & \multirow{3}{*}{5.915} \\
\hline & RPGOV2 & 5.758 & 3.223 & & 5.758 & 2.933 & \\
\hline & RPGOV3 & 6.342 & 2.907 & & 6.342 & 2.762 & \\
\hline \multirow{3}{*}{ Workplace-climate } & RPWORK1 & 8.107 & 2.478 & \multirow{3}{*}{7.839} & 8.107 & 1.680 & \multirow{3}{*}{7.839} \\
\hline & RPWORK2 & 7.636 & 2.769 & & 7.636 & 1.868 & \\
\hline & RPWORK3 & 7.774 & 2.629 & & 7.774 & 2.147 & \\
\hline REPUTATION & & & & 6.235 & & & 7.411 \\
\hline \multirow{3}{*}{ Pragmatic-Legitimacy } & LEGP1 & 6.279 & 2.552 & \multirow{3}{*}{6.123} & 7.635 & 2.429 & \multirow{3}{*}{7.485} \\
\hline & LEGP2 & 6.272 & 2.634 & & 7.600 & 2.470 & \\
\hline & LEGP3 & 5.819 & 2.609 & & 7.219 & 2.200 & \\
\hline \multirow{3}{*}{ Moral- Legitimacy } & LEGM1 & 4.205 & 3.299 & & 6.832 & 2.677 & \\
\hline & LEGM2 & 3.899 & 3.247 & 4.380 & 6.455 & 2.589 & 6.814 \\
\hline & LEGM3 & 5.035 & 3.002 & & 7.154 & 2.488 & \\
\hline & LEGCOG1 & 5.508 & 2.628 & & 7.078 & 2.166 & \\
\hline Cognitive- & LEGCOG2 & 5.433 & 2.629 & 5.147 & 7.080 & 2.203 & 6.765 \\
\hline & LEGCOG3 & 4.500 & 2.991 & & 6.136 & 2.705 & \\
\hline LEGITIMACY & & & & 5.217 & & & 7.021 \\
\hline & IMAGCOG1 & 6.886 & 2.007 & & 8.145 & 1.654 & \\
\hline Cognitive-Image & IMAGCOG2 & 7.049 & 2.091 & & 8.420 & 1.587 & \\
\hline & IMAGCOG3 & 5.072 & 2.891 & 5.862 & 6.683 & 2.548 & 7.142 \\
\hline & IMAGCOG4 & 4.439 & 2.800 & & 5.321 & 2.355 & \\
\hline & IMAF1 & 6.797 & 2.183 & & 7.603 & 2.037 & \\
\hline Affective-Image & IMAF2 & 5.450 & 2.612 & 5.979 & 6.818 & 2.480 & 7.308 \\
\hline & IMAF3 & 5.690 & 2.521 & & 7504 & 2,198 & \\
\hline IMAGE & & & & 5.920 & & & 7.225 \\
\hline
\end{tabular}

Note: SD: Standard deviation.

The next step was to verify the reliability and validity of the measurement model for both stakeholder groups (Tables 4 and 5). 
Table 4. Reliability and validity (students).

\begin{tabular}{|c|c|c|c|c|c|c|c|}
\hline \multicolumn{8}{|c|}{ Students } \\
\hline \multirow{2}{*}{ Factor } & \multirow{2}{*}{ Item } & Weights/ & \multirow{2}{*}{$t$-Value } & \multirow{2}{*}{ VIF } & \multirow{2}{*}{ CA } & \multirow{2}{*}{ CR } & \multirow{2}{*}{ AVE } \\
\hline & & Loadings & & & & & \\
\hline \multirow[t]{3}{*}{ Performance } & RPPERF1 & 0.457 & 8.459 & 1.921 & & & \\
\hline & RPPERF2 & 0.278 & 4.784 & 2.087 & & & \\
\hline & RPPERF3 & 0.403 & 6.248 & 2.294 & & & \\
\hline \multirow[t]{2}{*}{ Innovation } & RPIN1 & 0.464 & 10.239 & 1.807 & & & \\
\hline & RPIN2 & 0.628 & 14.408 & 1.807 & & & \\
\hline \multirow[t]{3}{*}{ Citizenship } & RPCSR1 & 0.454 & 10.249 & 1.918 & & & \\
\hline & RPCSR2 & 0.179 & 5.045 & 1.546 & & & \\
\hline & RPCSR3 & 0.543 & 12.881 & 1.550 & & & \\
\hline \multirow[t]{3}{*}{ Services } & RPSER1 & 0.222 & 3.757 & 2.170 & & & \\
\hline & RPSER2 & 0.483 & 8.434 & 2.651 & & & \\
\hline & RPSER3 & 0.427 & 8.853 & 1.826 & & & \\
\hline \multirow[t]{3}{*}{ Governance } & RPGOV1 & 0.453 & 11.657 & 1.611 & & & \\
\hline & RPGOV2 & 0.470 & 11.628 & 1.863 & & & \\
\hline & RPGOV3 & 0.250 & 6.630 & 2.027 & & & \\
\hline \multirow{3}{*}{ Workplace-climate } & RPWORK1 & 0.373 & 8.022 & 2.122 & & & \\
\hline & RPWORK2 & 0.129 & 3.090 & 1.843 & & & \\
\hline & RPWORK3 & 0.605 & 12.147 & 2.428 & & & \\
\hline \multirow{3}{*}{ Pragmatic-L. } & LEGP1 & 0.943 & 133.654 & & 0.933 & 0.957 & 0.882 \\
\hline & LEGP2 & 0.944 & 99.844 & & & & \\
\hline & LEGP3 & 0.930 & 115.444 & & & & \\
\hline \multirow{3}{*}{ Moral-L. } & LEGM1 & 0.932 & 106.855 & & 0.819 & 0.892 & 0.734 \\
\hline & LEGM2 & 0.956 & 205.811 & & & & \\
\hline & LEGM3 & 0.892 & 78.146 & & & & \\
\hline \multirow{3}{*}{ Cognitive-L. } & LEGCOG1 & 0.792 & 30.063 & & 0.917 & 0.948 & 0.859 \\
\hline & LEGCOG2 & 0.917 & 116.160 & & & & \\
\hline & LEGCOG3 & 0.857 & 64.712 & & & & \\
\hline \multirow{4}{*}{ Cognitive-I. } & IMAGCOG1 & 0.196 & 6.017 & 1.544 & & & \\
\hline & IMAGCOG2 & 251 & 6.948 & 1.564 & & & \\
\hline & IMAGCOG3 & 0.540 & 17.852 & 1.457 & & & \\
\hline & IMAGCOG4 & 0.311 & 9.751 & 1.633 & & & \\
\hline \multirow{3}{*}{ Affective-I. } & IMAF1 & 0.254 & 5.310 & 2.339 & & & \\
\hline & IMAF2 & 0.445 & 7.339 & 4.334 & & & \\
\hline & IMAF3 & 0.381 & 6.859 & 3.764 & & & \\
\hline \multirow[t]{2}{*}{ Image } & Cognitive I. & 0.707 & 18.085 & 2.641 & & & \\
\hline & Affective I. & 0.343 & 7.990 & 2.641 & & & \\
\hline \multirow[t]{6}{*}{ Reputation } & Performance & 0.082 & 2.366 & 2.953 & & & \\
\hline & Innovation & 0.062 & 1.710 & 4.011 & & & \\
\hline & Citizenship & 0.309 & 8.132 & 4.085 & & & \\
\hline & Services & 0.100 & 2.843 & 3.911 & & & \\
\hline & Governance & 0.346 & 10.052 & 2.978 & & & \\
\hline & Workplace & 0.214 & 5.295 & 3.772 & & & \\
\hline \multirow[t]{3}{*}{ Legitimacy } & Pragmatic L. & 0.503 & 14.077 & 1.913 & & & \\
\hline & Moral L. & 0.330 & 9.296 & 2.341 & & & \\
\hline & Cognitive L. & 0.299 & 7.912 & 2.454 & & & \\
\hline
\end{tabular}

Note: CA: Cronbach Alpha; CR: Composite Reliability; AVE: Average Variance Extended; VIF: Variance Inflation Factor. 
Table 5. Reliability and validity (professors).

\begin{tabular}{|c|c|c|c|c|c|c|c|}
\hline \multicolumn{8}{|c|}{ Professors } \\
\hline \multirow{2}{*}{ Factor } & \multirow{2}{*}{ Item } & Weights/ & \multirow{2}{*}{$t$-Value } & \multirow{2}{*}{ VIF } & \multirow{2}{*}{ CA } & \multirow{2}{*}{ CR } & \multirow{2}{*}{ AVE } \\
\hline & & Loadings & & & & & \\
\hline \multirow[t]{3}{*}{ Performance } & RPPERF1 & 0.746 & 6.481 & 1.736 & & & \\
\hline & RPPERF2 & 0.224 & 2.080 & 1.618 & & & \\
\hline & RPPERF3 & 0.164 & 1.221 & 1.991 & & & \\
\hline \multirow[t]{2}{*}{ Innovation } & RPIN1 & 0.638 & 5.230 & 2.833 & & & \\
\hline & RPIN2 & 0.412 & 3.253 & 2.833 & & & \\
\hline \multirow[t]{3}{*}{ Citizenship } & RPCSR1 & 0.392 & 2.718 & 2.269 & & & \\
\hline & RPCSR2 & 0.185 & 2.038 & 2.095 & & & \\
\hline & RPCSR3 & 0.560 & 5.033 & 1.770 & & & \\
\hline \multirow[t]{3}{*}{ Services } & RPSER1 & 0.304 & 2.286 & 2.080 & & & \\
\hline & RPSER2 & 0.537 & 2.927 & 3.359 & & & \\
\hline & RPSER3 & 0.260 & 1.544 & 2.699 & & & \\
\hline \multirow[t]{3}{*}{ Governance } & RPGOV1 & 0.145 & 1.207 & 1.929 & & & \\
\hline & RPGOV2 & 0.672 & 5.161 & 1.799 & & & \\
\hline & RPGOV3 & 0.308 & 2.948 & 2.112 & & & \\
\hline \multirow{3}{*}{ Workplace-climate } & RPWORK1 & 0.111 & 0.962 & 3.105 & & & \\
\hline & RPWORK2 & 0.027 & 0.272 & 1.990 & & & \\
\hline & RPWORK3 & 0.895 & 9.662 & 2.519 & & & \\
\hline \multirow{3}{*}{ Pragmatic-L. } & LEGP1 & 0.922 & 32.445 & & 0.907 & 0.941 & 0.843 \\
\hline & LEGP2 & 0.929 & 39.182 & & & & \\
\hline & LEGP3 & 0.903 & 29.304 & & & & \\
\hline \multirow{3}{*}{ Moral-L. } & LEGM1 & 0.950 & 74.926 & & 0.836 & 0.902 & 0.754 \\
\hline & LEGM2 & 0.952 & 80.206 & & & & \\
\hline & LEGM3 & 0.897 & 36.205 & & & & \\
\hline \multirow{3}{*}{ Cognitive-L. } & LEGCOG1 & 0.855 & 22.195 & & 0.925 & 0.953 & 0.871 \\
\hline & LEGCOG2 & 0.921 & 65.565 & & & & \\
\hline & LEGCOG3 & 0.826 & 21.316 & & & & \\
\hline \multirow{4}{*}{ Cognitive-I. } & IMAGCOG1 & 0.166 & 1.599 & 1.818 & & & \\
\hline & IMAGCOG2 & 0.369 & 3.385 & 1.897 & & & \\
\hline & IMAGCOG3 & 0.411 & 4.744 & 1.200 & & & \\
\hline & IMAGCOG4 & 0.412 & 5.832 & 1.246 & & & \\
\hline \multirow{3}{*}{ Affective-I. } & IMAF1 & 0.363 & 3.276 & 3.412 & & & \\
\hline & IMAF2 & 0.279 & 1.944 & 5.352 & & & \\
\hline & IMAF3 & 0.434 & 3.289 & 3.372 & & & \\
\hline \multirow[t]{2}{*}{ Image } & Cognitive I. & 0.653 & 9.108 & 2.373 & & & \\
\hline & Affective I. & 0.409 & 5.217 & 2.373 & & & \\
\hline \multirow[t]{6}{*}{ Reputation } & Performance & -0.047 & 0.796 & 3.528 & & & \\
\hline & Innovation & 0.031 & 0.487 & 4.231 & & & \\
\hline & Citizenship & 0.514 & 6.830 & 4.011 & & & \\
\hline & Services & 0.081 & 1.279 & 3.376 & & & \\
\hline & Governance & 0.327 & 6.247 & 2.081 & & & \\
\hline & Workplace & 0.208 & 2.565 & 3.298 & & & \\
\hline \multirow[t]{3}{*}{ Legitimacy } & Pragmatic L. & 0.443 & 5.459 & 1.836 & & & \\
\hline & Moral L. & 0.298 & 3.003 & 2.653 & & & \\
\hline & Cognitive L. & 0.401 & $4, .181$ & 2.234 & & & \\
\hline
\end{tabular}


When considering the reflective items, the following elements were identified. All the Cronbach's alphas surpassed the recommendation of $0.70[68,69]$. The value of the composite reliability for legitimacy's reflective items is over 0.60, therefore they appear under the correct scope [70]. Moreover, the average variance extracted (AVE) was calculated, and all items present values over 0.50 , which is considered appropriate [71]. The standardized loadings of the reflective items and their significant levels show that they are significantly linked to their dimensions and constructs. Finally, the discriminant validity (HTMT) is presented in Table 6 showing that the obtained values are lower than 0.85 , which represents an acceptable level [72].

Table 6. Discriminant validity (HTMT).

\begin{tabular}{|c|c|c|c|c|c|c|}
\hline \multirow[b]{2}{*}{ Factor } & \multicolumn{3}{|c|}{ Students } & \multicolumn{3}{|c|}{ Professors } \\
\hline & $\begin{array}{l}\text { Cognitive } \\
\text { Legitimacy }\end{array}$ & $\begin{array}{c}\text { Moral } \\
\text { Legitimacy }\end{array}$ & $\begin{array}{l}\text { Pragmatic } \\
\text { Legitimacy }\end{array}$ & $\begin{array}{l}\text { Cognitive } \\
\text { Legitimacy }\end{array}$ & $\begin{array}{c}\text { Moral } \\
\text { Legitimacy }\end{array}$ & $\begin{array}{l}\text { Pragmatic } \\
\text { Legitimacy }\end{array}$ \\
\hline \multicolumn{7}{|l|}{ Cognitive Legitimacy } \\
\hline Moral Legitimacy & 0.823 & & & 0.801 & & \\
\hline Pragmatic Legitimacy & 0.736 & 0.676 & & 0.636 & 0.696 & \\
\hline
\end{tabular}

Regarding the formative constructs, the collinearity (VIF) value is presented, showing that every item is under the appropriate level [65] except for the IMAF2. Moreover, the standardized weights are shown in both tables, as are their significant values, showing that all formative values affect in a meaningful manner to their dimensions in the case of students, while, for professors, some items' weights are not significant. For the second order values, students show that innovation is not a significant dimension with respect to the reputation construct, and in the case of the professors, innovation, performance, and services dimensions appear as not significant. However, since the loadings of these dimensions were high, the dimensions were maintained [65].

In order to develop the MGA, the acceptability of the models, as well as the measurement invariance, need to be established. For this purpose, Henseler, Ringle and Sarstedt [73] offered the measurement invariance of composite method (MICOM) for PLS-SEM (Partial Least Squares), which is applied in this study to assess measurement invariance. Table 7 presents partial measurement invariance, which is a requirement for the comparison and interpretation of the MGA's group differences, using the results from PLS-SEM [73].

Table 7. Results of Invariance Measurement Testing Using Permutation.

\begin{tabular}{cccccccccccc}
\hline & Configural Invariance & \multicolumn{2}{c}{ Compositional Invariance } & \multicolumn{2}{c}{ PMI } & \multicolumn{2}{c}{ Equal Mean Assessment } & \multicolumn{3}{c}{ Equal Variance Assessment } & \multicolumn{2}{c}{ FMI } \\
\hline Constructs & & C = & CI & & Diff & CI & \multicolumn{2}{c}{ EqualDiff } & CI & Equal & No \\
\hline Legitimacy & Yes & 0.99 & $(0.98 ; 1.00)$ & Yes & $-0,68$ & $(-0.19 ; 0.18)$ & No & 0.12 & $(-0.26 ; 0.33)$ & Yes & No \\
Image & Yes & 0.99 & $(0.99 ; 1.00)$ & Yes & $-0,65$ & $(-0.19,0.19)$ & No & 0.23 & $(-0.25 ; 0.33)$ & Yes & No \\
Reputation & Yes & 0.99 & $(0.98 ; 1.00)$ & Yes & $-0,75$ & $(-0.19,0.19)$ & No & 014 & $(-0.26 ; 0.34)$ & Yes & No \\
\hline
\end{tabular}

Note: PMI = Partial Measurement Invariance; FMI = Full Measurement Invariance; CI = Confidence Interval.

Finally, Table 8 presents the results of the structural model assessment. The results show that, for students and professors, image positively and significantly affects legitimacy, that legitimacy positively and significantly affects reputation, and that image positively and significantly affects reputation. The multigroup analysis presents the results on the MGA path coefficients' comparison, and the findings show no significant differences between students and professors regarding the three proposed hypotheses. In this research, all the methods used for the multigroup analysis support the same conclusion of not identifying significant differences by stakeholder group in the relationship between image and legitimacy, legitimacy and reputation, and image and reputation, thus providing a multimethod confirmation of our results. 
Table 8. Hypothesis testing.

\begin{tabular}{|c|c|c|c|c|c|}
\hline \multirow[b]{2}{*}{ Hypothesis } & \multicolumn{2}{|c|}{ Students } & \multicolumn{2}{|c|}{ Professors } & \multirow[t]{2}{*}{ Supported } \\
\hline & Beta & $t$-value & Beta & $t$-value & \\
\hline H1 Image-Legitimacy & 0.844 & 62.636 & 0.825 & 25.678 & Yes \\
\hline H2 Legitimacy-Reputation & 0.439 & 12.328 & 0.411 & 5.547 & Yes \\
\hline H3 Image-Reputation & 0.904 & 90.531 & 0.918 & 54.008 & Yes \\
\hline \multicolumn{6}{|c|}{$\begin{aligned}{ }^{*} \mathrm{R}^{2} \text { students }\left(\text { Legitimacy) }=0.713 ;{ }^{*} \mathrm{R}^{2} \text { professors }(\text { Legitimacy) }\right. & =0.681 ;{ }^{*} \mathrm{Q}^{2} \text { students }\left(\text { Legitimacy) }=0.521 ;{ }^{*} \mathrm{Q}^{2} \text { professors }\left(\text { Legitimacy) }=0.479 * \mathrm{R}^{2}\right.\right. \\
\text { students }(\text { Reputation })=0.873 ;{ }^{*} \mathrm{R}^{2} \text { professors }(\text { Reputation }) & =0.896 ;{ }^{*} \mathrm{Q}^{2} \text { students }(\text { Reputation })=0.633{ }^{*} \mathrm{Q}^{2} \text { professors }(\text { Reputation })=0.590\end{aligned}$} \\
\hline & \multicolumn{4}{|c|}{$p$-Value Difference } & \\
\hline & Path Coefficient Difference & Parametric Test & Henseler MGA & Permutation Test & Supported \\
\hline H4 Image-Legitimacy & 0.019 & 0.556 & 0.302 & 0.512 & $\mathrm{No}, \mathrm{No}, \mathrm{No}$ \\
\hline H4 Legitimacy-Reputation & 0.028 & 0.736 & 0.363 & 0.764 & $\mathrm{No}, \mathrm{No}, \mathrm{No}$ \\
\hline H4 Image-Reputation & 0.045 & 0.585 & 0.715 & 0.621 & No, No, No \\
\hline
\end{tabular}

Note: MGA: Multigroup Analysis.

\section{Discussion}

Higher education institutions have understood the multiple benefits that holding a positive image, legitimacy, and reputation can provide in terms of improving their competitive position [13], regaining public trust, and offering a quality sign [35] to reduce uncertainty [14] for stakeholders [15,36]. Therefore, the introduction of these intangible assets as a priority for universities can be considered a sustainable strategy in order to survive and succeed in the exiting competitive scenarios. However, the complexity of managing these variables has increased due to the difficulty of meeting the variety of universities' stakeholders' requirements; therefore, it is crucial for these institutions to identify the different perceptions held by their diverse groups.

The results show that the level of the variables under consideration varies depending on the stakeholder group. Students have valued their university's legitimacy in 5.22 over 10, while professors consider that the legitimacy level is 7.02. The results of image show that the obtained level in the case of the evaluation made by students is 5.92, and for professors it is 7.23. Finally, for the value of reputation, the students evaluate it at 6.24 and professors at 7.41. The differences between the evaluations made by each group could be mainly related to their diverse characteristics in terms of age, knowledge, or degree of commitment with the institution. Since professors are internal stakeholders, they might have a greater sense of belonging and might be more informed on aspects related to the university compared to students. External stakeholders, such as students, might be more demanding, which results in lower evaluations. These results relate to the arguments supported by [74], [75] or [3] that highlight the complexity of managing intangible assets in the higher education field due to the different characteristics of their stakeholders. Regarding these results, a university's manager can know which aspects of their university's image, reputation, and legitimacy have lower values for professors and students; therefore, it provides ideas on which aspects to improve first.

First, the results on the value of image, legitimacy, and reputation appear on the middle part, considering the use of a 10-point Likert scale (0: strongly disagree; 10: strongly agree) in the case of students and in the middle-upper part in the case of the evaluations made by professors. Second, as the evaluations made by professors are higher for every variable, managers should try to identify which aspects could be more relevant for their students in order to get them more involved in their relationship with their university and to improve their image, legitimacy, and reputation in order to obtain more consistent assessment through stakeholder groups. In the case of legitimacy, since the moral dimension is the lowest one, they should develop actions to improve their right to exists as well as their behavior in order to be considered as trustworthy. Regarding the image level, it would be important to continue improving aspects that affect both elements. In relation to reputation, the governance dimension appears as the lowest factor for both stakeholders; therefore, the appropriate university's managers' behavior remains as one of the most determinant elements to improve.

When considering the different dimensions of image, legitimacy, and reputation, the following elements were discovered. In the case of the pragmatic, moral, and cognitive dimensions of legitimacy, 
our findings confirm the significance of all three factors, and the weights of each of them are similar for both students and professors. Therefore, the dimensions proposed by Suchman [11] could be confirmed through this research. When taking into consideration the cognitive and affective dimension considered for the university's image, both elements appear as significant for both stakeholder groups; however, in both cases, the cognitive dimension has a higher weight. Under this situation, the model developed by Beerli-Palacio, Díaz-Meneses, and Pérez [64] on measuring the university's image could be confirmed through our research. Finally, when taking into consideration the six dimensions developed by Vidaver-Cohen [39] the results show that the innovation dimension is not significant for students. In the case of professors, the dimensions of performance, innovation, and services appear as not significant.

Connecting the results on the descriptive analysis and on the weights of the different dimensions of the three considered variables, managers should analyze the importance of each dimension in the global perception of each construct and the actual levels held according to the students' and professors' perceptions and evaluations. For example, when considering the governance dimension of reputation, students and professors consider that the level held by their university is low and the weight of this dimension over total reputation is one of the highest. Under this situation, a university's managers should identify this as a critical point and start by improving the behavior of their governance structure in order to achieve better results.

Regarding the structural model, our findings confirm the three proposed hypotheses because a positive and significant relationship exists between image and legitimacy, legitimacy and reputation, and image and reputation. In the case of the first hypothesis, this confirmation was already supported by authors in the field [46-48]. When considering the second hypothesis on the effect that legitimacy has on reputation, the obtained results meet the research developed by $[16,53-59,63,76]$. Finally, when analyzing the results on the third proposed hypothesis (the effect that image has on reputation), our findings were already supported by scholars such as [46,49,77-79], among others. When analyzing the obtained results in terms of the moderating effect that the stakeholder group has on the relationship between the three variables, hypothesis four was not confirmed because there are no significant differences in the way that the variables relate for students and professors. Therefore, even though the image, legitimacy, and reputation evaluations made by stakeholder group differ, the way these variables relate does not present important differences.

First, the relevance of identifying the influence that image, legitimacy, and reputation have on each other has been demonstrated by presenting additional empirical evidence on a relatively innovative field since we have proved that these variables are different but highly related. Second, these relationships can serve as guidance for university managers when trying to manage intangible assets. When considering the first proposed hypothesis, managers can develop actions to improve their image and, as a result these actions, will also have a positive impact on the legitimacy of the given university. In addition, all actions and strategies aimed to increase legitimacy will have an impact on the institution's reputation as well. Finally, when universities are developing actions to improve their image, if performed properly they will improve the institution's reputation. Considering that resources are limited, it is interesting to identify these types of relationships because a university's managers can benefit from synergies caused by how closely related they are. Almost any action or strategy aimed at increasing one of them will have an impact on the others.

In addition, regarding the results on the moderating effect of the stakeholder group, the way in which a positive assessment of how one of the intangible assets would affect another would be similar for both students and professors. However, it is important to understand that these two stakeholder groups might be affected by different criteria when making their image, legitimacy, and reputation evaluations because, as it has been proven through this research, they show differences in the image, legitimacy, and reputation level of their university as well as on the weights and significance of the dimensions forming each construct. Under these circumstances, it is important to highlight 
the relevance of managing the relationship with both stakeholder groups in order to improve the university's image, legitimacy, and reputation.

Within the limitations and future research lines of the given paper, three main points could be highlighted. First, the sample was a unique Spanish Public University, where, even though the size of the sample was wide enough, a deeper understanding could be reached through an analysis of a higher number of universities in the Spanish higher education context. Second, universities have more than two stakeholder groups, and for this research, only two of the most important groups where considered, without including additional stakeholders' perspectives for the comparison of the results. Third, since one of the stakeholder groups considered (professors) are part of the university, their responses could be biased based on their link with the institution; however, a high number of questions were introduced to reduce this possible effect. Moreover, since it was not possible to receive data from all the students and professors from the university under study, we have assumed the representativeness of the sample; however, not having more data could be a limitation for this research. The future research lines relate to meeting these points: A wider range of public universities should be analyzed, along with a greater number of stakeholder groups, in order to develop a comparative analysis.

Author Contributions: Conceptualization, C.D.-C.-F., A.B.-G., and R.D.-A.; methodology, C.D.-C.-F. and A.B.-G.; software, C.D.-C.-F.; validation, R.D.-A.; formal analysis, C.D.-C.-F. and A.B.-G.; investigation, C.C., A.B.-G., and R.D.-A.; data curation, C.D.-C.-F., A.B.-G., and R.D.-A.; writing-original draft preparation, C.D.-C.-F.; visualization, C.D.-C.-F. and R.D.-A.; supervision, A.B.-G.; project administration, C.D.-C.-F. and R.D.-A. All authors have read and agreed to the published version of the manuscript.

Funding: This research received no external funding.

Acknowledgments: This research was supported by Fundación Camilo Prado.

Conflicts of Interest: The authors declare no conflict of interest.

\section{References}

1. Amaia, L.R.D.S.; Pilar, Z.; Forcada, J. A review of higher education image and reputation literature: Knowledge gaps and a research agenda. Eur. Res. Manag. Bus. Econ. 2017, 24, 8-16.

2. Altbach Philip, G.; Reisberg, L.; Rumbley, L.E. Tracking a global academic revolution. Chang. Mag. High. Learn. 2010, 42, 30-39. [CrossRef]

3. Christensen, T.; Gornitzka, Å. Reputation Management in Complex Environments-A Comparative Study of University Organizations. High. Educ. Policy 2017, 30, 123-140. [CrossRef]

4. Hemsley-Brown, J.; Melewar, T.C.; Nguyen, B.; Wilson, E.J. Exploring brand identity, meaning, image, and reputation (BIMIR) in higher education: A special section. J. Bus. Res. 2016, 69, 3019-3022. [CrossRef]

5. Plewa, C.; Ho, J.; Conduit, J.; Karpen, I.O. Reputation in higher education: A fuzzy set analysis of resource configurations. J. Bus. Res. 2016, 69, 3087-3095. [CrossRef]

6. Verčič, A.T.; Verčič, D.; Žnidar, K. Exploring academic reputation-is it a multidimensional construct? Corp. Commun. Int. J. 2016, 21, 160-176. [CrossRef]

7. Barron, G.R.S. The Berlin Principles on Ranking Higher Education Institutions: Limitations, legitimacy, and value conflict. High. Educ. 2017, 73, 317-333. [CrossRef]

8. Phair, J.T. 1992 Education Report Card. Public Relat. J. 1992, 48, 22.

9. Hand, J.R.; Lev, B. Intangible Assets: Values, Measures, and Risks: Values, Measures, and Risks; OUP: Oxford, UK, 2003.

10. Lev, B.; Zarowin, P. The boundaries of financial reporting and how to extend them. J. Account. Res. 1999, 37, 325-385. [CrossRef]

11. Suchman, M. Managing legitimacy: Strategic and institutional approaches. Acad. Manag. Rev. 1995, 20, 571-610. [CrossRef]

12. Zimmerman, M.A.; Zeitz, G.J. Beyond survival: Achieving new venture growth by building legitimacy. Acad. Manag. Rev. 2002, 27, 414-431. [CrossRef]

13. Parameswaran, R.; Glowacka, A.E. University image: An information processing perspective. J. Mark. High. Educ. 1995, 6, 41-56. [CrossRef] 
14. Rindova, V.P.; Williamson, I.O.; Petkova, A.P. Being Good or Being Known: An Empirical Examination of the Reputation. Acad. Manag. J. 2005, 48, 1033-1049. [CrossRef]

15. Munisamy Susila, J.; Noor Ismawati, M.; Nagaraj, S. Does reputation matter? Case study of undergraduate choice at a premier university. Asia Pac. Educ. Res. 2014, 23, 451-462. [CrossRef]

16. Deephouse, D.L.; Suchman, M. Legitimacy in organizational institutionalism. SAGE Handb. Organ. Inst. 2008, 49, 77 .

17. Chun, R. Corporate reputation: Meaning and measurement. Int. J. Manag. Rev. 2005, 7, 91-109. [CrossRef]

18. Deephouse, D.L. Media reputation as a strategic resource: An integration of mass communication and resource-based theories. J. Manag. 2000, 26, 1091-1112. [CrossRef]

19. Arpan, L.M.; Raney, A.A.; Zivnuska, S. A cognitive approach to understanding university image. Corp. Commun. An Int. J. 2003, 8, 97-113. [CrossRef]

20. Aghaz, A.; Hashemi, A.; Sharifi Atashgah, M.S. Factors contributing to university image: The postgraduate students' points of view. J. Mark. High. Educ. 2015, 25, 104-126. [CrossRef]

21. Maringe, F. Strategies and challenges of internationalisation in HE: An exploratory study of UK universities. Int. J. Educ. Manag. 2009, 23, 553-563. [CrossRef]

22. Alves, H.; Raposo, M. The influence of university image on student behaviour. Int. J. Educ. Manag. 2010, 24, 73-85. [CrossRef]

23. Curtis, T.; Abratt, R.; Minor, W. Corporate brand management in higher education: The case of ERAU. J. Prod. Brand Manag. 2009, 18, 404-413. [CrossRef]

24. Duarte, P.O.; Alves, H.B.; Raposo, M.B. Understanding university image: A structural equation model approach. Int. Rev. Public Nonprofit Mark. 2010, 7, 21-36. [CrossRef]

25. Wilkins, S.; Huisman, J. Factors affecting university image formation among prospective higher education students: The case of international branch campuses. Stud. High. Educ. 2015, 40, 1256-1272. [CrossRef]

26. Alessandri, S.W.; Yang, S.U.; Kinsey, D.F. An integrative approach to university visual identity and reputation. Corp. Reput. Rev. 2006, 9, 258-270. [CrossRef]

27. Stensaker, B.; Norgård, J.D. Innovation and isomorphism: A case-study of university identity struggle 1969-1999. High. Educ. 2001, 42, 473-492. [CrossRef]

28. Rodriguez-Pomeda, J.; Casani, F. Legitimating the world-class university concept through the discourse of elite universities' presidents. High. Educ. Res. Dev. 2016, 35, 1269-1283. [CrossRef]

29. Khurana, R.; Nohria, N. It's time to make management a true profession. Harv. Bus. Rev. 2008, 86, 70-77.

30. Del-Castillo-Feito, C.; Blanco-González, A.; González-Vázquez, E. The relationship between image and reputation in the Spanish public university. Eur. Res. Manag. Bus. Econ. 2019, 25, 87-92. [CrossRef]

31. Bitektine, A. Toward a Theory of Social Judgments of Organisations: The Case of Legilimacy, Reputation, and Status. Acad. Manag. Rev. 2011, 36, 151-179. [CrossRef]

32. Farrugia, C.A.; Lane, J.E. Legitimacy in Cross-Border Higher Education: Identifying Stakeholders of International Branch Campuses. J. Stud. Int. Educ. 2013, 17, 414-432. [CrossRef]

33. Alajoutsijarvi, K.; Juusola, K.; Siltaoja, M. The Legitimacy Paradox of Business Schools: Losing by Gaining? Acad. Manag. Learn. Educ. 2015, 14, 277-291. [CrossRef]

34. Suomi, K. Exploring the dimensions of brand reputation in higher education-A case study of a Finnish master's degree programme. J. High. Educ. Policy Manag. 2014, 36, 646-660. [CrossRef]

35. Nguyen, N.; LeBlanc, G. Image and reputation of higher education institutions in students' retention decisions. Int. J. Educ. Manag. 2001, 15, 303-311. [CrossRef]

36. Hemsley-Brown, J. The best education in the world': Reality, repetition or cliché? International students' reasons for choosing an English university. Stud. High. Educ. 2012, 37, 1005-1022. [CrossRef]

37. Aula, H.; Tienari, J. Becoming "world-class"? Reputation-building in a university merger. Crit. Perspect. Int. Bus. 2011, 7, 7-29. [CrossRef]

38. Šontaitè, M.; Bakanauskas, A. Measurement model of corporate reputation at higher education institutions: Customers' perspective. Organ. Vadyb. Sist. Tyrim. 2011, 59, 115-130.

39. Vidaver-Cohen, D. Reputation beyond the rankings: A conceptual framework for business school research. Corp. Reput. Rev. 2007, 10, 278-304. [CrossRef]

40. Volkwein, J.F.; Sweitzer, K.V. Institutional prestige and reputation among research universities and liberal arts colleges. Res. High. Educ. 2006, 47, 129-148. [CrossRef] 
41. Watkins, B.A.; Gonzenbach, W.J. Assessing university brand personality through logos: An analysis of the use of academics and athletics in university branding. J. Mark. High. Educ. 2013, 23, 15-33. [CrossRef]

42. Suomi, K.; Järvinen, R. Tracing reputation risks in retailing and higher-education services. J. Retail. Consum. Serv. 2013, 20, 207-217. [CrossRef]

43. Brewer, A.; Zhao, J. The impact of a pathway college on reputation and brand awareness for its affiliated university in Sydney. Int. J. Educ. Manag. 2010, 24, 34-47. [CrossRef]

44. Ali, R.; Lynch, R.; Melewar, T.C.; Jin, Z. The moderating influences on the relationship of corporate reputation with its antecedents and consequences: A meta-analytic review. J. Bus. Res. 2015, 68, 1105-1117. [CrossRef]

45. Foreman Peter, O.; Whetten David, A.; Mackey, A. An identity-based view of reputation, image, and legitimacy: Clarifications and distinctions among related constructs. Oxford Handb. Corp. Reput. 2012. [CrossRef]

46. Tran, M.A.; Nguyen, B.; Melewar, T.C.; Bodoh, J. Exploring the corporate image formation process. Qual. Mark. Res. An Int. J. 2015, 18, 86-114. [CrossRef]

47. MacLean, T.L.; Behnam, M. The dangers of decoupling: The relationship between compliance programs, legitimacy perceptions, and institutionalized misconduct. Acad. Manag. J. 2010, 53, 1499-1520. [CrossRef]

48. Metzler, M.S. Responding to the legitimacy problems of big tobacco: An analysis of the "people of Philip Morris" image advertising campaign. Commun. Q. 2001, 49, 366-381. [CrossRef]

49. Fombrun, C.J.; Van Riel, C.B. The Reputational Landscape. Corp. Reput. Rev. 1997, 1, 5-13. [CrossRef]

50. Fornell, C.; Rust, R.T.; Dekimpe, M.G. The effect of customer satisfaction on consumer spending growth. J. Mark. Res. 2010, 47, 28-35. [CrossRef]

51. Harvey, W.S.; Morris, T.; Müller Santos, M. Reputation and identity conflict in management consulting. Hum. Relat. 2017, 70, 92-118. [CrossRef]

52. Podnar, K.; Golob, U. The Quest for the Corporate Reputation Definition: Lessons from the Interconnection Model of Identity, Image, and Reputation. Corp. Reput. Rev. 2017, 20, 186-192. [CrossRef]

53. King, B.G.; Whetten, D.A. Rethinking the Relationship Between Reputation and Legitimacy: A Social Actor Conceptualization. Corp. Reput. Rev. 2008, 11, 192-207. [CrossRef]

54. Rao, H. The social construction of reputation: Certification contests, legitimation, and the survival of organizations in the American automobile industry: 1895-1912. Strateg. Manag. J. 1994, 15, 29-44. [CrossRef]

55. Deephouse, D.; Carter, S. An Examination of Differences Between Organizational Legitimacy and Organizational Reputation. J. Manag. Stud. 2005, 6, 3-23. [CrossRef]

56. Bansal, P.; Roth, K. Why companies go green: A model of ecological responsiveness. Acad. Manag. J. 2000, 43, 717-736.

57. Doh, J.P.; Howton, S.D.; Howton, S.W.; Siegel, D.S. Does the market respond to an endorsement of social responsibility? The role of institutions, information, and legitimacy. J. Manag. 2010, 36, 1461-1485. [CrossRef]

58. Fan, Y. Ethical branding and corporate reputation. Corp. Commun. Int. J. 2005, 10, 341-350. [CrossRef]

59. Czinkota, M.; Kaufmann, H.R.; Basile, G. The relationship between legitimacy, reputation, sustainability and branding for companies and their supply chains. Ind. Mark. Manag. 2014, 43, 91-101. [CrossRef]

60. Hörisch, J.; Freeman, R.E.; Schaltegger, S. Applying stakeholder theory in sustainability management: Links, similarities, dissimilarities, and a conceptual framework. Organ. Environ. 2014, 27, 328-346. [CrossRef]

61. Chaney, D.; Lunardo, R.; Bressolles, G. Making the store a place of learning: The effects of in-store educational activities on retailer legitimacy and shopping intentions. J. Bus. Res. 2016, 69, 5886-5893. [CrossRef]

62. Chung, J.Y.; Berger, B.K.; DeCoster, J. Developing measurement scales of organizational and issue legitimacy: A case of direct-to-consumer advertising in the pharmaceutical industry. J. Bus. Ethics 2016, 137, 405-413. [CrossRef]

63. Thomas, T.E. Are business students buying it? A theoretical framework for measuring attitudes toward the legitimacy of environmental sustainability. Bus. Strategy Environ. 2005, 14, 186-197. [CrossRef]

64. Beerli Palacio, A.; Díaz Meneses, G.; Pérez Pérez, P.J. The configuration of the university image and its relationship with the satisfaction of students. J. Educ. Adm. 2002, 40, 486-505. [CrossRef]

65. Hair, J.F., Jr.; Sarstedt, M.; Ringle, C.M.; Gudergan, S.P. Advanced Issues in Partial Least Squares Structural Equation Modeling; SAGE Publications: Southend Oaks, CA, USA, 2017.

66. Henseler, J.; Ringle, C.M.; Sarstedt, M. A new criterion for assessing discriminant validity in variance-based structural equation modeling. J. Acad. Mark. Sci. 2015, 43, 115-135. [CrossRef] 
67. Sarstedt, M.; Henseler, J.; Ringle, C.M. Multigroup analysis in partial least squares (PLS) path modeling: Alternative methods and empirical results. In Measurement and Research Methods in International Marketing; Emerald Group Publishing Limited: Bingley, UK, 2011; pp. 195-218.

68. Cronbach, L.J. Coefficient alpha and the internal structure of tests. Psychometrika 1951, 16, 297-334. [CrossRef]

69. Nunnally, J.C.; Bernstein, I.H. Psychometric Theory; McGraw-Hill: New York, NY, USA, 1994.

70. Bagozzi, R.P.; Yi, Y. On the evaluation of structural equation models. J. Acad. Mark. Sci. 1988, 16, 74-94. [CrossRef]

71. Fornell, C.; Larcker, D.F. Structural equation models with unobservable variables and measurement error: Algebra and statistics. J. Mark. Res. 1981, 18, 382-388. [CrossRef]

72. Clark, L.A.; Watson, D. Constructing validity: Basic issues in objective scale development. Psychol. Assess. 1995, 7, 309. [CrossRef]

73. Henseler, J.; Ringle, C.M.; Sarstedt, M. Testing measurement invariance of composites using partial least squares. Int. Mark. Rev. 2016, 33, 405-431. [CrossRef]

74. Fragueiro, F.; Thomas, H. Strategic Leadership in the Business School: Keeping One Step Ahead; Cambridge University Press: Cambridge, UK, 2011.

75. Whitley, B.E. Factors associated with cheating among college students: A review. Res. High. Educ. 1998, 39, 235-274. [CrossRef]

76. Martínez, N.O.; Carabel, T.C.; del Castillo Feito, C. Legitimacy and Reputation of Organizations: Their Relationship with Management Systems and Financial Performance. In Organizational Legitimacy; University of California Press: Berkeley, CA, USA, 2018; pp. 141-157.

77. Zineldin, M.; Akdag Hatice, C.; Vasicheva, V. Assessing quality in higher education: New criteria for evaluating students' satisfaction. Qual. High. Educ. 2011, 17, 231-243. [CrossRef]

78. Fombrun, C.; Shanley, M. What'S in a Name? Reputation Building and Corporate Strategy. Acad. Manag. J. 1990, 33, 233-258.

79. Saxton, M.K. Where do reputations come from? Corp. Reput. Rev. 1998, 1, 393-399. [CrossRef]

(C) 2020 by the authors. Licensee MDPI, Basel, Switzerland. This article is an open access article distributed under the terms and conditions of the Creative Commons Attribution (CC BY) license (http://creativecommons.org/licenses/by/4.0/). 